\title{
気管支狭窄症の内科的治療における PCPS の有用性
}

\author{
近藤裕香理 中前健二 竹中利尾 古田邦彦 山本康数 中山受
}

【要旨】当院では気管支狭窝症に対し硬性気管支鏡を用いたレーザー焼灼術, ステント留雷術とい つた気管支鏡下治療が增加傾向にある。今回我々は，治療中の呼吸補助を目的に PCPS を施行した 症例を経験した。症例は気管支狭窄症の気管支鏡下治療をPCPS 下にて行った男性 2 名, 女性 1 名 の計 4 例（同一患者を含む）であった。脱血は大腿静脈（右房脱血）, 送血は 3 例で大腿動脈 (V-A bypass), 1 例て内頊静脈 (V-V bypass)にて行った。灌流量は $2.0 \mathrm{~L} / \mathrm{min}, \mathrm{FiO}_{2} 100 \%$, 酸素流量 $2.0 \mathrm{~L} / \mathrm{min}$ にて開始し, 両手の $\mathrm{SpO}_{2}$ およ゙右手の動脈血ガス分析を指標として灌流量を適宜調整

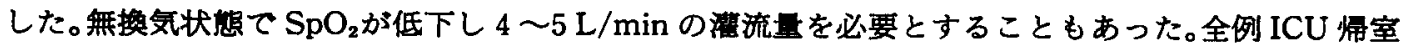
後にPCPS を離脱でき，人工呼吸器も翌日に離脱することができた。PCPSを用いた呼吸補助は简 便であり，安全に治療を行うためには有用であると考えられた。ただし，術前の心肺機能，気管支 の狭䬥度を評洒し，患者ごとの送脱血法も検討する必要があることも考えられた。

Key words : 気管支狭寉症, 呼吸補助, PCPS

\section{I . 目的}

経皮的心肺補助法 (Percutaneous Cardio Pulumonary Support：以下 PCPS)は，迅速かつ简 便な心肺補助手段として広く受け入れられるように なり, 循環器内科における治療をはじめ, 呼吸器内 科や救急の現場でも積極的に適用されるようになっ てきた。当院においても PCPS 補助下に気管支狭窝 症の気管支鏡下治療が増加傾向にある。気管支狭窄 症例では，気管捜管が困難な場合または，治療中に 完全な無換気状態に楩る場合も少なくない。そこで 我々は，気管支狭窑症に対し硬性気管支鏡を用いた レーザー燒灼術，ステント留置術などの気管支鏡下 治療中, PCPSにて呼吸補助を施行した症例を経験 したので若干の考察を加え報告する。

\section{II. 症例}

症例は，気管支狭窟症の気管支鏡下治療を PCPS 下にて行った男性 2 名, 女性 1 名の計 4 例（同一患 者を含む)であった。心機能は 1 例で前壁梗塞を認 めたが $\mathrm{EF}$ は正常であり, 全例肺実質に問題は認め られなかった。

\section{1, 症例 1}

40 歳女性て, 労作時呼吸困難にて近医受診, 気管 内に巨大䤚瘦が認められ手術目的にて当院に紹介さ
れた。来院時, 気道狭䆩を示すWheezing 聴取 し, 肺機能検查では 1 秒率 $38.5 \%$ と典型的な閉塞性 換気障害を示した。ガス分析およびその他の検査所 見には異常は想められなかった。気管支鏡検查およ び $3 \mathrm{D}-\mathrm{CT}$ に示すごとく腫場が気道の $90 \%$ 以上を 閉塞する所見が認められた（図 1 )。

2. 症例 2

58 歳, 男性。労作時呼吸困難にて近医受診, 縦隔 嗹瘍による気管圧迫と診断され，ステント留置術を 目的に当院に紹介となった。来院時, Wheezing を諗 めるもののガス分析，心電図，レントゲン検查では 異常は認められなかった。

\section{3. 症例 3}

55 歳男性で心筋梗塞にて近医入院時, 人工呼吸器 管理が行われた。その後, 気管内に肉芽腫が形成さ れ，呼吸困難にて手術目的で当院に紹介となった。 来院時, 胸部聴診で吸気・呼気ともに狭窄音が認め
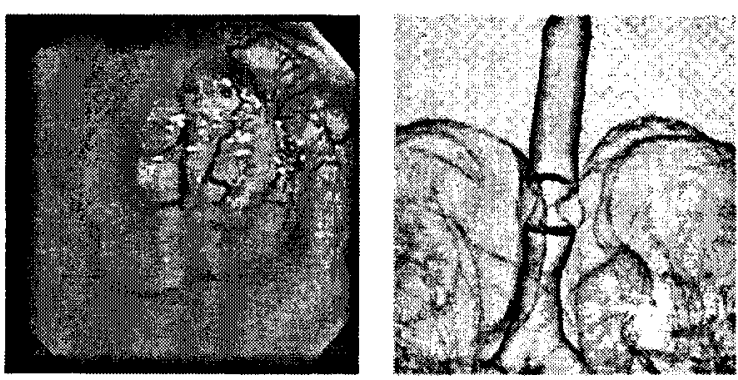

図 I気管支鏡所見＆3 D-CT 画像（症例Ｉ） 
られた。肺機能検查では，1秒率 $38.5 \%$ と閉塞性換 気障害を示した。治療前に行われた気管支鏡検查で は，気管支径は $4 \mathrm{~mm}$ であった。治療は，気管支狭 窄部位に対して気管支焼灼術を施行した（図 2 ）。

1 回目の治療後 1 ケ月で再び気道狭䂟となり, $\mathrm{PaCO}_{2}=98.6 \mathrm{mmHg}, \mathrm{CO}_{2}$ ナルコーシスにて緊急入 院となった。気管挿管困難のため換気ができず, ICU 入室後 $\mathrm{PaCO}_{2}=193 \mathrm{mmHg}$ まで上昇したため, $\mathrm{V}-\mathrm{V}$ bypassでの PCPS 管理となった。翌日ステント留 置術を施行した。

\section{III. 方 法}

\section{I．回路および抗凝固凨}

PCPS キットは，全例テルモ社製キャピオックス EBS キットを用い, 送血：15 Fr, 脱血：18 Fr のカ ニューレを使用した。脱血は大腿静脈（右房脱血）, 送血は 3 例で大腿動脈 (V-A bypass)，1例で内頝 静脈 ( $\mathrm{V}-\mathrm{V}$ bypass) にて行った。なお，体外循環中 の抗凝固療法は 1 例でヘパリン, 3 例でメシル酸ナ ファモスタットを用いACTで 150〜200 秒にて適 宜調節した。

\section{2. 開始条件}

体外循環の灌流量は $2.0 \mathrm{~L} / \mathrm{min}$, 酸素流量は, 2.0 $\mathrm{L} / \mathrm{min}, \mathrm{FiO}_{2}=100 \%$ で開始した。体外循環中, 灌流 量などの条件は血行動態およびガス動態, 特に右手 の $\mathrm{SpO}_{2}$ を指標にして適宜調整した。
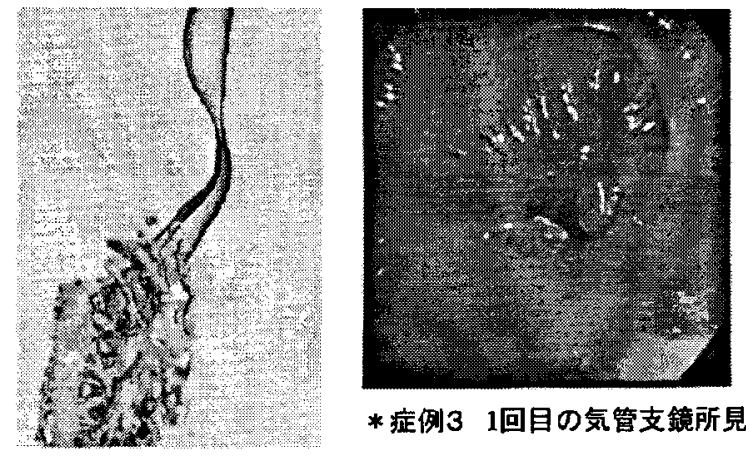

*症例3 1回目の気管支鏡所見

图 23 D-CT 画像（症例 2）\&気管支鏡所見（症例 3）
表 I 手術方法と PCPS 濩流条件

Perfusion MAX Pump 02 flow/Fi02 operation Bypass -time(min) flow (L/min) (L/min / $\%$ )

(1) レーザー烧灼術 V-A $116 \min 4.0 \quad 3.0 \sim 30.0 / 100$

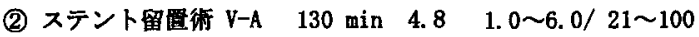

(3) ステント㜣纳術 V-A $125 \min 4.3 \quad 1.0 \sim 6.0 / 60 \sim 100$

(4) レーザー烧灼術 V-V *2265 $\min 4.5 \quad 2.0 \sim 15.0 / 100$ ナステント留䁖術

*術前日よりC02ナルコーシスにて䋈入院、 ICUでECLA管理となった症例

体外循環中の抗凝固療法注1例でヘパリン、3例で メシル酸ナファモスタットを用いACTで150〜200秒 にて調節した。

\section{IV. 結 果}

硬性気管支鏡を用いた術式はレーザー焼灼術 2 例, ステント留置術 1 例，レーザー焼灼術を行った後, ステント留置術を行った1例であった。PCPSによ るバイパス方法は大垠静脈 (右房) 脱血-大腿動脈送 血の $\mathrm{V}-\mathrm{A}$ bypass 3 例, 大腿静脈 (右房) 脱血-内頝 静脈（右房）送血の V-V bypass 1 例であった。体 外循環時間は術前日から V-V bypassを行った 1 症例を除き116〜130 分であった。また術中の換気状 態により灌流量を平均 $4 \sim 5 \mathrm{~L} / \mathrm{min}$,酸素流量を最 大 : $30 \mathrm{~L} / \mathrm{min}$ にて対応した（表 1)。

I. 症例 I

送・脱血チューブをカニューレーションした後, 灌流量： $2.0 \mathrm{~L} / \mathrm{min}$ にて補助循環を開始し，麻酔導 入を行った。硬性気管支鏡挿入前に呼吸扣制が見ら れ，右手の $\mathrm{SpO}_{2} お$ よび血圧の低下を認めたため灌 流量の調整にて対応した。呼吸抑制が認められたと きの血液ガスは, $\mathrm{PaCO}_{2}=60 \mathrm{mmHg}, \mathrm{PaO}_{2}=50$ $\mathrm{mmHg}$ であった。PCPSの離脱は手術室にて行い, ICU へ帰室となった（図 3 ）。

2. 症例 2

ステント留置術施行中に気管支粘膜損傷により換 気困難，血圧低下となり緊急にて PCPSによる呼吸

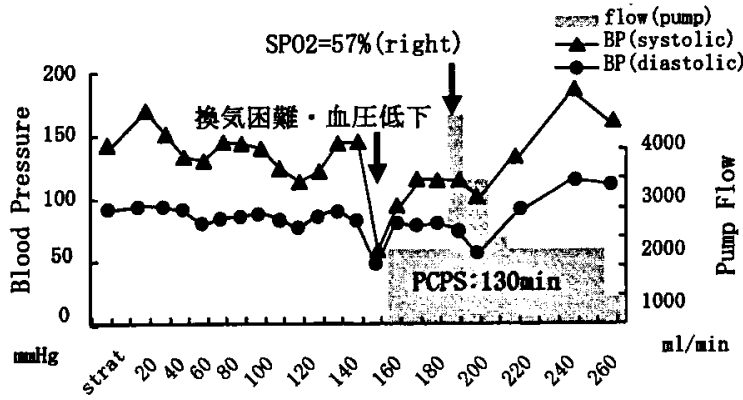

図 4 血行動態と PCPS : 櫵流量経時的变化（症例 2) 
補助療法を行った。PCPSによる呼吸補助を行うこ とで血行動㿟は一時安定するも，術中の換気状態に より $\mathrm{SpO}_{2}$ が 57\%まで低下したため, 灌流量の調整 にて対応した。ステント留贯後のガス動態は安定し ていたが PCPS 装着のまま ICU に帰室し PCPSの 離脱を行った（図 4 ）。

\section{3. 症例 3}

1 回目は V-A bypass, 2 回目は $\mathrm{V}-\mathrm{V}$ bypass $に$ て術前より PCPSによる呼吸補助を行った。2 回と も血行動態は安定していたが，1回目の手術では, 一時的な狭窄部位の開塞により $\mathrm{PCO}_{2}=91 \mathrm{mmHg}$ と高炭酸ガス血症を来たし， 2 回目の手術において も術中の操作にて $\mathrm{PO}_{2}=48.7 \mathrm{mmHg}$ と低酸素血症 を認め，满流量および酸素流量の調整にて対応した。 2 回とも PCPS の離脱は, ICU 㷌室後に行われた (図 5,6)。

\section{V. 考 管}

PCPS システムを用いた体外循骤は送脱血部位に よって，V-A bypassまたは $\mathrm{V}-\mathrm{V}$ bypassに分けら れる(図 7 )。通常はV-A bypass が用いられ，特徵 は呼吸補助と同時に循謤補助が可能である点である。 循謤補助としては，右心負荷の軽減は右心不全の状 態には有効と考えられる。しかし，左心系への補助 効果はあまり期待できない。特に心機能低下時に PCPS 灌流量が多いと，大動脈圧などの上昇を来た し，左心系の後負荷が増大する可能性がある。今回，

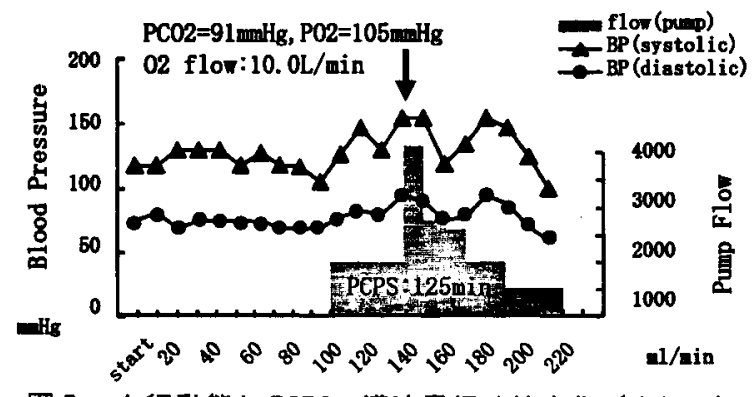

図 5 血行勒热と PCPS：櫵流量経時的変化（症例 3 ）

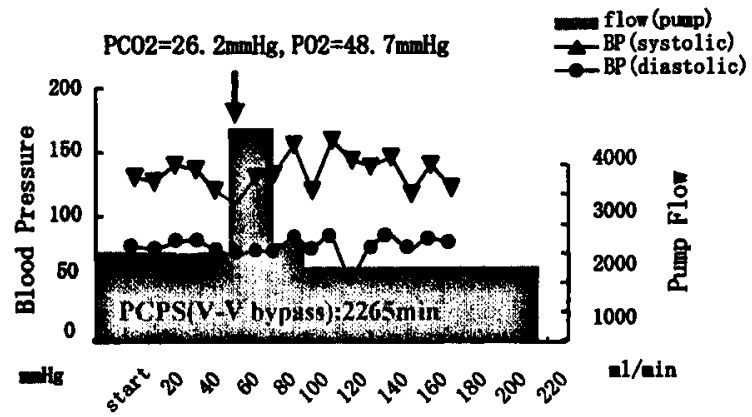

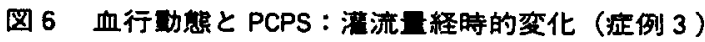

ほとんどの症例では，治療中に低換気状態となり， 一時的に灌流量を $4 \sim 5 \mathrm{~L} / \mathrm{min}$ まで増やしており， 左心系の後負荷が増加した可能性も考えられた。

また, V-A bypass では, 送血部位が大腿動脈であ るため，自己の心拍出量が多い場合には人工肺で酸 素加された血液が上半身に到達せず，体内酸素分圧 が不均一となる可能性がある。そのため，脳や心臟 などの重要葴器に酸素加血が濩流されず，腹部臓器 に主として酸素加血が灌流する傾向となる。今回の 症例においても，低換気状態となったときには，左 右の $\mathrm{SpO}_{2} に は$ 著しい差が見られ，PCPS 灌流量の 増加でも容易には右手の $\mathrm{SpO}_{2}$ の上昇は見られなか った。また，回路内にできた塞栓がそのまま動脈系 へ流れる危険性があると言われている。灌流量が増 加すると体動脈の拍動がなくなり，このために堅血 流量が減少し腎機能障害を来たすことがあるとも文 われている。

一方, V-V bypass は, 同一静脈系での bypass で あり，送・脱血の調整が容易で, V-A bypass のよう な左心系への負荷は認められない。血菠が右心系に 戻されるので，肺動脈，体動脈に酸素飽和度の一棣 な血液が流れることになりかつ拍動流が得られる。 しかし, 直接的な循環補助効果は得られず，右心負 荷が軽減されることはない。また，高流量補助の場 合には，送血血液が直接再脱血される可能性があり， 呼吸・循環補助ともに限界があると言われてい $3^{1-3)}$ 。

硬性気管支鏡を用いた手術では一時的に無換気状 態となることがある。陽圧換気併用下と完全な気道 開塞状態・無換気状態では，体外循環による適正な 灌流量が異なる。特に後者では，適切な灌流量を維 持することが重要となる。循環補助も必要となる場 合には，心拍出量の $60 \%$ ～ $80 \%$ 灌流量を要する。 呼吸状態不良の場合には高心拍出量状態ということ もあり，更に多量の灌流量が必要と考えられる1。 こで,気道閉塞・無換気時では $4 \sim 5 \mathrm{~L} / \mathrm{min}$ の灌流量 が必要となると言える。以上より手術の進行状況を
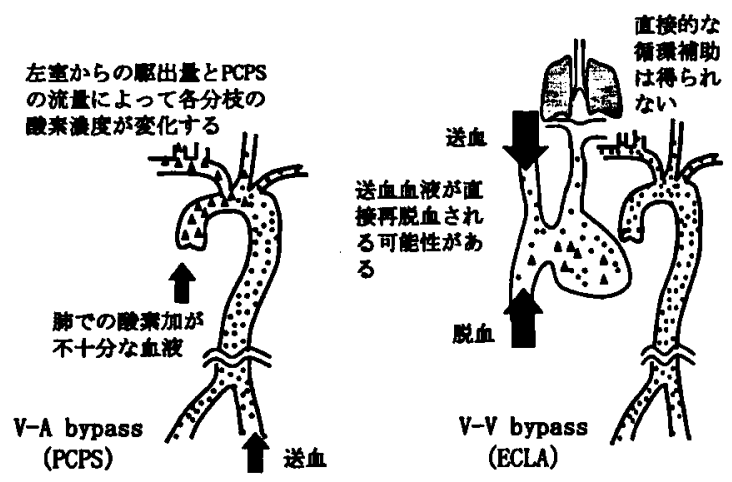

图 7 Bypass 方法 
把握した適切な PCPS 操作・管理が求められる。ま た，bypass方法による利点・欠点を充分に理解した 上で, 術前の心機能, 肺機能, 気管支の狭窄度を評 価し，各症例にあった送・脱血法を検討する必要が あると考えられた。

\section{VI. 結 語}

(1) PCPS 補助下に硬性気管支鏡を用いた治療を 4 例経験した。

(2) PCPS キットを用いた呼吸補助法は簡便であり, 安全に手術を行うためにはPCPSによる呼吸補 助法は有用であると考えられた。

(3) bypass 方法による利点・欠点を充分に理解した
上で, 術前の心機能, 肺機能, 気管支の狭窄度を 評価し，各症例にあった送・脱血法を検討する必 要があると考えられた。

\section{- 参考文献}

1）松田 暉 監：経皮的心肺補助法. 初版, 東京, 秀 潤社. 1998.p.121-122.

2 ) 阿部稳雄 編：最新 人工心肺. 初版, 名古屋, 名 古屋大学出版会. 1999.p.204.

3 ）草川 貫 編：体外循環の実際. 初版, 東京. 南江 堂. 1991.p.210 211. [本論文は, 第 30 回日本体外循環技術研究会大会にて
報告した。 